\title{
THE IMPACT OF TOURISM UNCERTAINTY ON AIRLINE STOCK MARKETS IN KOREA: A QUANTILE REGRESSION APPROACH
}

\author{
Ji-Hong JEON(1)* \\ School of Business, Hanyang University, Seoul, Korea \\ Received 04 February 2020; accepted 01 March 2021
}

\begin{abstract}
This study explores the impact of tourism uncertainty, including economic policy uncertainty (EPU) and travel crises arising from issues such as terrorism and disease outbreaks, on airline stock markets in Korea. Airline stock prices are particularly affected by tourism uncertainty. Using data from 2001-2018 and events influencing tourism uncertainty such as the 9/11 terrorist attacks and severe acute respiratory syndrome, quantile regression approach reveals how EPU influences airline stock prices in Korea during three market phases - bearish, normal, and bullish. EPU and travel crises negatively affect airline stock prices in Korea. Specifically, we document that higher EPU and more global travel crises lead to deeper reductions in stock prices in bullish markets. These results provide implications and insights for airline investors, stakeholders, and organizations concerned about the influence of tourism uncertainty on airline stock prices in Korea.
\end{abstract}

Keywords: Korea, economic policy uncertainty, travel crisis, airline, stock market, quantile regression.

JEL Classification: G12, M21, Z30.

\section{Introduction}

Economic policy uncertainty (EPU) has been discussed extensively in the literature on tourism (Alegre et al., 2013; Antonakakis et al., 2013; Balli et al., 2018; Madanoglu \& Ozdemir, 2019). More recently, economic recession, political corruption, and terrorism have also been considered to be sources of tourism uncertainty that affect outbound tourists (Arana \& León, 2008; Bonham et al., 2006; Dhariwal, 2005). However, there has been limited discussion on the link of tourism uncertainty on airline stock prices. It would be interesting to investigate the effect of EPU on airline stock prices in a country. Therefore, we extend the association between tourism uncertainty and airline stock prices by using the EPU index in Korea.

Tourism is becoming an important sector of the world economy. For example, international tourist arrivals increased 6\% to 1.4 billion in 2018 compared with 2017 (UNWTO,

\footnotetext{
${ }^{\star}$ Corresponding author. E-mail: cellc@hanyang.ac.kr
} 
2019). The expansion of the tourism industry is now one of the major determinants of economic growth (Jang \& Chen, 2008). In 2018, Korea was ranked ninth among the world's top expenders on international tourism. Overseas travel is considered a major milestone in the life of an average Korean (Kim et al., 2012). Recently, tourist expenditure has increased significantly in line with the rapid economic growth in Korea. According to the World Economic Outlook database (International Monetary Fund, 2019), gross domestic product (GDP) in Korea was US\$ 1.619 trillion in 2018, of which tourism expenditure accounted for US\$28.414 billion, up from US\$27.960 billion in 2017. Specifically, GDP per capita in Korea was US\$ 31,345 in 2018, of which average tourism expenditure per capita accounted for US\$ 990, or roughly $3 \%$ of the economy. Moreover, since the end of 2019, world tourism has been in a severe crisis due to the coronavirus disease 2019 pandemic. Compared with the same period last year, international tourist arrivals fell by $72 \%$ in January to October 2020 (UNWTO, 2020).

The tourism sector is one of the key industries for promoting private consumption and national economic growth (Dritsakis, 2004; Lee \& Chang, 2008; Olya \& Mehran, 2017). Therefore, tourism activity affects economic development (Hannam et al., 2014; Sinclair, 1998), and the tourism industry impacts various industry sectors and their stock returns (Kavussanos et al., 2002). Stock prices, which indicate the growth of a company, are an important indicator of economic growth. Indeed, the stock price index not only interacts with consumption changes in tourism and other industries, but also has a close link with macroeconomic variables related to the tourism sector (Chang \& Lee, 2017; Demir et al., 2017; Napierala \& Szutowski, 2018). Similarly, EPU often results in a drop in tourism consumption (Ongan \& Gozgor, 2017). Serious risks, such as the 9/11 terrorist attacks in 2001 in the United States and severe acute respiratory syndrome (SARS) outbreak first identified at the end of February 2003 by the World Health Organization, can increase travel crises and change stock prices (Chen et al., 2005).

We explore the association of tourism uncertainty and risk, including EPU and travel crises, on airline stock index (ASI) in Korea. The research questions in this study are twofold. First, this study explores how EPU influences airline stock prices in Korea by categorizing it into three phases that correspond to bearish, normal, and bullish markets using quantile regression (QR), which is a departure from previous EPU studies (Balli et al., 2018; Gozgor \& Ongan, 2017). While using ordinary least squares (OLS) regression only shows the mean effect between the dependent and explanatory variables, employing the QR approach shows whether EPU affects stock prices under different market conditions (You et al., 2017). Therefore, the QR approach is more robust (Chen, 2016). Second, using the QR approach allows us to examine how airline stock prices in Korea are affected by travel crises such as $9 / 11$ and SARS.

The remainder of this paper is organized as follows. Section 1 reviews the literature. Section 2 provides the data and methodology. Section 3 details the results using the QR approach. Section 4 presents the discussion, and the final section concludes. 


\section{Literature and hypotheses}

\subsection{Literature review}

Tourism researchers have noted the association between stock prices and macroeconomic variables (Napierala \& Szutowski, 2018; Wong \& Song, 2006) as well as non-economic variables such as the Olympics and terrorist attacks (Chen, 2007; Veraros et al., 2004). The macroeconomic variables used in this study are in line with those in the literature, namely, outbound tourism expenditure per capita (OBTE), oil prices, exchange rates (EX), and industrial production (IP), which have been identified as major factors influencing stock prices (Chang, 2020; Demir et al., 2017; Miller \& Ratti, 2009; Narayan et al., 2020). When the public's concerns about travel risk increases, OBTE declines because of a fall in travel demand (Demir et al., 2017; Gholipour et al., 2014; Nguyen et al., 2020; Rosselló et al., 2017), which in turn negatively affects tourism stock returns. If crude oil prices increase, this raises the revenue and income of oil and oil-related industries (Broadstock et al., 2012; Kang et al., 2015; Park \& Ratti, 2008). Furthermore, crude oil prices positively affect airline stock prices because increases in fuel prices heighten the value of airlines (Kristjanpoller \& Concha, 2016; Narayan \& Sharma, 2011). Further, stock prices are closely linked to the economy. Stock prices and EX are negatively related to the portfolio balance effect (Tsai, 2012; Wong, 2017). Particularly, EX depreciation results in an upward spiral of inflation, leading to skepticism from investors and ultimately a decline in stock prices (Ajayi \& Mougoue, 1996). Moreover, IP is related to the overall economic conditions of a country (Asprem, 1989; Kavussanos et al., 2002), and it increases when the economy expands, which boosts the sales and income of firms. Consequently, a booming economy results in rising stock prices (Chen, 2007). Finally, events such as $9 / 11$ and SARS can affect travelers' health and safety and thus tourism companies' stock prices (Demir et al., 2017; Wong \& Song, 2006).

Studies on the influence of EPU on stock markets have increased recently (Chang et al., 2015; Christou et al., 2017; Demir \& Ersan, 2018; Ko \& Lee, 2015). Baker et al. (2016) developed EPU indexes for over 20 countries, including the United States, China, and Korea, to examine EPU trends over time. In addition, EPU affects OBTE, which is directly connected to the income of tourism companies, including airlines, and the increase (decrease) in companies' earnings leads to a bullish (bearish) stock market (Demir \& Gozgor, 2018; Dragouni et al., 2016). This research therefore examines the association of tourism uncertainty, considering EPU and travel crises such as terrorism and disease outbreaks, on airline stock prices in Korea.

\subsection{Hypotheses}

This study suggests two hypotheses for airline stock prices. The first relates to the negative link between EPU and stock markets (Li \& Peng, 2017). Higher EPU lowers stock prices. Thus, the following hypothesis can be developed.

Hypothesis 1. A rise in Korean EPU lowers airline stock prices in the country, especially when the stock market is particularly bullish. 
Meanwhile, a number of studies have examined economic crises and tourism (Sheldon \& Dwyer, 2010) as well as tourism crises, such as terrorism and disease outbreaks (Dolnicar, 2005; Kolaric \& Schiereck, 2016). Particularly, research has assessed the association of terrorist attacks, such as 9/11, on the stock market (Chen, 2007; Mnasri \& Nechi, 2016). Some research has revealed the effects of global influenza pandemics, such as SARS, on outbound tourists in Asian countries (Chen et al., 2018; Pine \& McKercher, 2004; Wan, 2013). Therefore, to estimate the association of global travel crises, which threaten travelers' safety, on airline stock prices in Korea, the second hypothesis is stated as follows:

Hypothesis 2. The increase in global travel crises, such as the 9/11 and SARS, which increases EPU, decreases airline stock prices in Korea, especially when the stock market is particularly bullish.

\section{Data and methodology}

\subsection{Data}

The dependent variable is the ASI, which is based on the stock prices of the major airlines listed on the Korea Exchange, Korean Air, and Asiana Air, obtained from Yahoo Finance website, following Demir and Ersan (2018). The explanatory variables are derived from the following sources: EPU index for South Korea (Economic Policy Uncertainty Index for South Korea, 2018), OBTE from the Korea Tourism Organization, jet fuel price (FUEL) from the Energy Information Administration in the United States, EX from the Bank of Korea, and IP from Statistics Korea. This research applies the QR approach using monthly data from January 2001 to December 2018.

Figure 1 shows the quarterly tourism expenditure of outbound travelers departing from Korea. It shows that tourism expenditure declines sharply due to travelers' uncertainty about

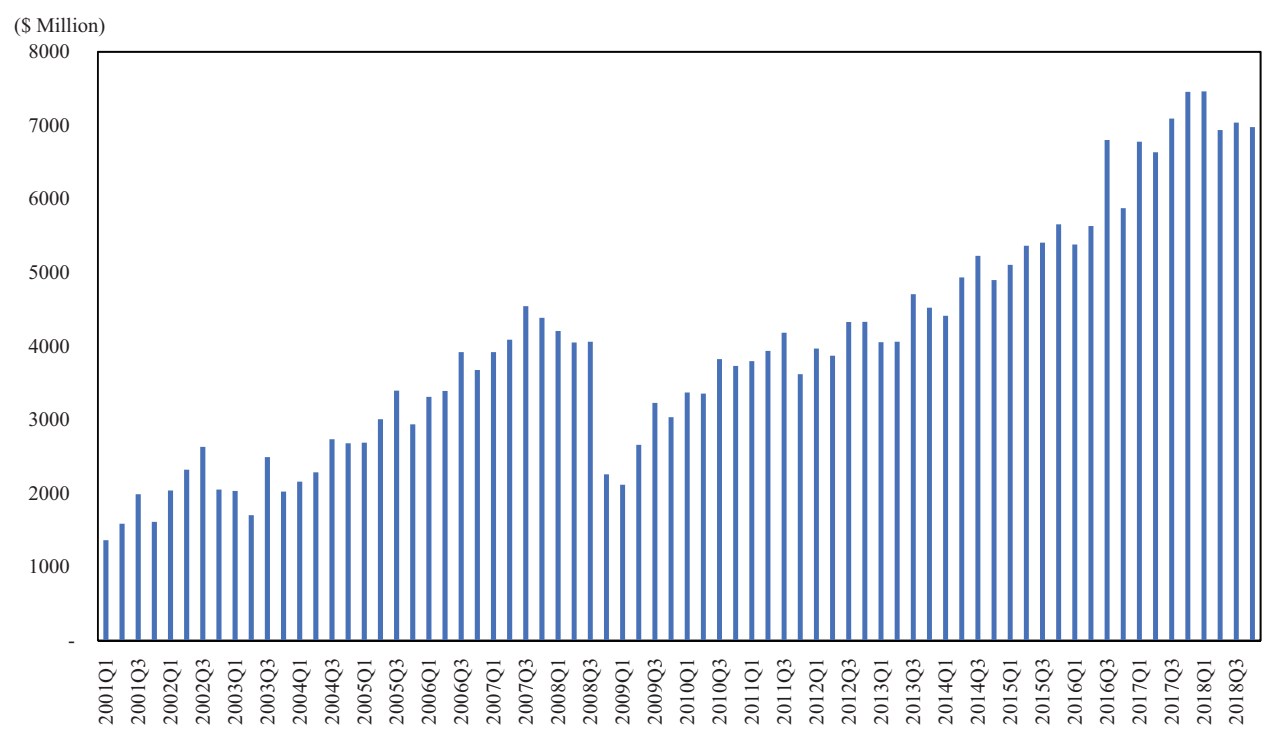

Figure 1. International tourist expenditure and global events in Korea (2001-2018) 
their safety following events such as $9 / 11$ and SARS. OBTE is used to estimate tourism demand. Similarly, the two events of $9 / 11$ and SARS are used to create the dummy variables following Kim et al. (2012). We expect these dummy variables to have negative coefficients; in other words, they significantly influence the stock market as they are directly related to travelers' safety (Chen et al., 2005).

In Figure 2, an increase in EPU negatively affects the ASI in Korea. EPU increases sharply due to the risk of travel following events such as 9/11 and SARS. Therefore, outbound international travel and tourism expenditure decrease.

Figure 3 presents the average operating costs based on the annual reports of the top two Korean airlines, Korean Air and Asiana Air, which accounted for 82.7\% of domestic airline sales in 2018, from 2016 to 2018. FUEL accounts for a major proportion (25\%) of the airlines'

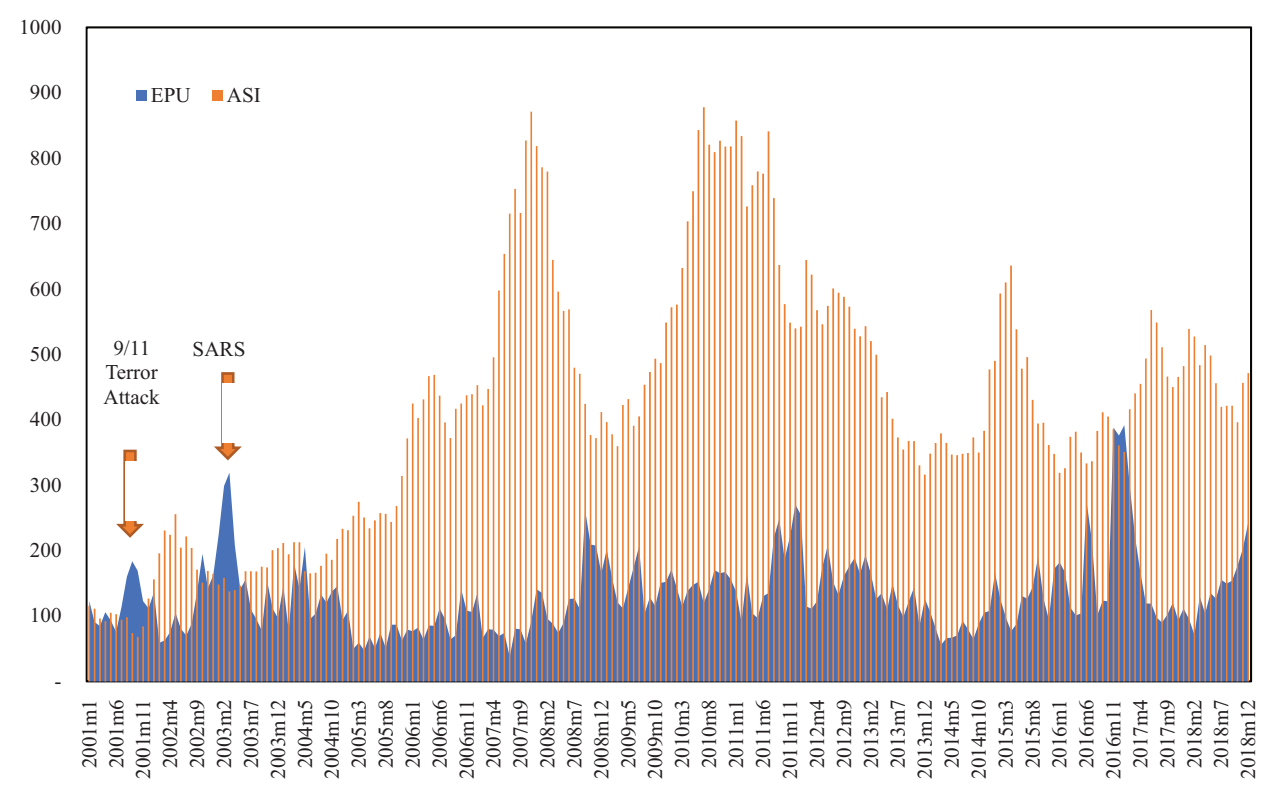

Note: EPU and ASI indicate monthly data on EPU and the ASI in Korea, respectively.

Figure 2. Trends of EPU and the ASI in Korea (2001-2018)

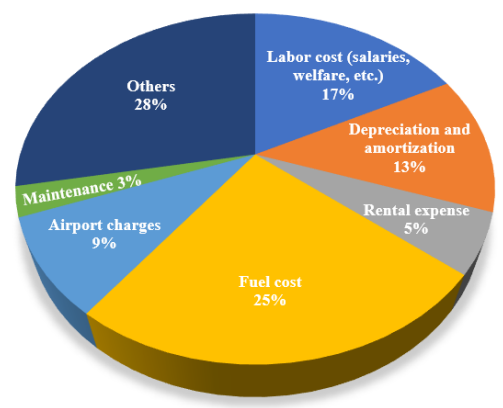

Figure 3. Operating cost breakdown of airlines in Korea (2016-2018) 
expenses, more than labor costs (17\%), depreciation and amortization (13\%), airport charges (9\%), and maintenance costs (3\%). As FUEL has a strong influence on the airlines' operating costs, their earnings are affected by swings in FUEL (Lim \& Hong, 2014; Yun \& Yoon, 2019). Therefore, FUEL is used as an explanatory variable in this study.

\subsection{Methodology}

Previous studies examining the association of EPU and travel crises on tourism stock prices have constructed a number of models (Chen, 2007; Demir \& Ersan, 2018; Kim et al., 2012). Based on them, the following log-linear models are developed to estimate the effects of a Korean EPU shock and global travel crises on airline stock prices in Korea to test our two hypotheses. Model 1 is constructed to test the effect of a EPU shock on the ASI. To estimate whether travel crises influence the ASI, we add two dummy variables, d9/11 for 9/11 (coded 1 if between September 2001 and November 2001, 0 otherwise) and dSARS for the SARS outbreak (coded 1 if between March 2003 and June 2003, 0 otherwise), into Models 2 and 3 along with the macro-level variables, namely, $\ln (\mathrm{EPU}), \ln (\mathrm{OBTE}), \ln (\mathrm{FUEL}), \ln (\mathrm{EX})$, and $\ln (\mathrm{IP})$. Therefore, Models 1 and 2 show the regression analyses to test the hypotheses. The equations of Models 1 and 2 are omitted for convenience. In Model 3, we investigate the simultaneous impact of EPU and travel crises on airline stock markets in Korea to observe their combined effects. The QR model is specified as follows:

$$
\begin{aligned}
& \ln \left(A S I_{t}\right)=\alpha+\beta_{1} \ln \left(E P U_{t}\right)+\beta_{2} \ln \left(\text { OBTE }_{t}\right)+\beta_{3} \ln \left(F U E L_{t}\right)+\beta_{4} \ln \left(E X_{t}\right)+ \\
& \beta_{5} \ln \left(I P_{t}\right)+\beta_{6} d 9 / 11+\beta_{7} d S A R S+\varepsilon_{t} .
\end{aligned}
$$

Unlike OLS analysis, the QR methodology allows the explanatory variables to differ by quantile (Koenker \& Bassett, 1978). The quantile estimator is given by solving the following optimization problem under the QR approach (Altunbaş \& Thornton, 2019):

$$
\min _{b \in R^{K}}\left[\sum_{i \in\left\{i: y_{i} \geq x_{i} \beta\right\}} \theta\left|y_{i}-x_{i} \beta\right|+\sum_{i \in\left\{i: y_{i}<x_{i} \beta\right\}} 1-\theta\left|y_{i}-x_{i} \beta\right|\right],
$$

where, for the $\theta$ th quantile $(0<\theta<1)$, yi indicates the ASI as the dependent variable and $\chi_{i}$ denotes a $k \times 1$ vector of the independent variables. To estimate the $\mathrm{QR}$ in this research, nine quantiles are selected following Nusair and Al-Khasawneh (2018). The hypotheses testing also follows Nusair and Olson (2019), who divided the stock market into three phases. Specifically, the lower quantiles $(\tau=0.1,0.2$, and 0.3$)$ represent a bearish market, which means a period of stock depreciation with pessimism, the medium quantiles $(\tau=0.4,0.5$, and 0.6$)$ correspond to a normal market, and the higher quantiles $(\tau=0.7,0.8$, and 0.9$)$ correspond to a bullish market, which denotes a period of stock appreciation with optimism. Hence, this study compares the OLS and QR approaches using nine quantiles of the ASI and the explanatory variables in the three models above. Models 1 and 2 envision the link of EPU and travel crises, respectively, using the dummy variables for the ASI in Korea. In Model 3, both EPU and the crises dummy variables are used to estimate their combined effects. 


\section{Results}

Table 1 shows the summary statistics of the monthly data of the variables during 2001-2018.

Table 1 . Summary statistics $(N=216)$

\begin{tabular}{|l|l|c|c|c|c|c|}
\hline \multicolumn{1}{|c|}{ Variables } & \multicolumn{1}{|c|}{ Definition } & Mean & Median & Min & Max & Std. Dev. \\
\hline ASI & Airline stock index & 421.20 & 416.34 & 67.98 & 877.81 & 196.75 \\
\hline EPU & $\begin{array}{l}\text { Economic policy } \\
\text { uncertainty index }\end{array}$ & 131.69 & 121.36 & 37.31 & 391.80 & 59.50 \\
\hline OBTE & $\begin{array}{l}\text { Outbound tourism } \\
\text { expenditure per capita } \\
\text { (US\$ 1,000) }\end{array}$ & 1.16 & 1.16 & 0.86 & 1.51 & 0.13 \\
\hline FUEL & $\begin{array}{l}\text { Jet fuel spot price } \\
\text { (US\$ per Gallon) }\end{array}$ & 1.89 & 1.81 & 0.52 & 3.89 & 0.82 \\
\hline EX & $\begin{array}{l}\text { Exchange rate } \\
\text { (KRW/US\$) }\end{array}$ & $1,123.63$ & $1,125.35$ & 907.40 & 1516.40 & 108.74 \\
\hline IP & Industrial production & 86.72 & 88.25 & 54.60 & 116.50 & 14.74 \\
\hline
\end{tabular}

First, EPU has a significant effect on the ASI in Model 1. EPU has a negative impact, particularly in bullish markets in Korea. This result is similar to that of Peng et al. (2018), who found that stock prices are sensitive to EPU shocks in bullish markets. The coefficient of OBTE is positive and significant. FUEL has a significantly positive association with the ASI in all quantiles. These results are consistent with those of Narayan and Sharma (2011) that oil prices positively influence stock market returns in the energy and transportation sectors in the United States. If oil prices increase, this predicts that economic growth will begin soon (Kristjanpoller \& Concha, 2016). Although the coefficients of EX are not significant in the higher quantiles, the results in the lower and medium quantiles are consistent with previous evidence of the significant negative association between the ASI and EX. Given the Korean won/US dollar rate, a positive (negative) change indicates the depreciation (appreciation) of the Korean won (Bang \& Park, 2018; Kim \& Kim, 2017). IP has a significantly positive link with the ASI in all quantiles. As the IP index is a proxy for real economic activity, it has a strong link with tourism arrivals (Karimi et al., 2019). Therefore, IP decreases during an economic recession and increases during an economic expansion. Indeed, Sadorsky (1999) provided evidence that positive stock return shocks increase global economic activity by increasing IP. In addition, the pseudo R-squared values show that the lower quantiles have greater explanatory power than the higher quantiles. The OLS results are also presented for reference. The results from the OLS model show that the coefficients of FUEL and IP are positive and significant, similar to those in our QR. However, EPU, OBTE, and EX have no significant effect on the ASI in the OLS model.

In Model 2, the dummy variables d9/11 and dSARS negatively influence the ASI. The coefficient of $d 9 / 11$ is negatively significant, consistent with the finding of Chen et al. (2005). In addition, the coefficient of dSARS is negatively significant, similar to the results of Chen and Kim (2010) and Kim et al. (2012). The results in Model 2 are similar to those in Model 
1 in that the coefficient of OBTE is positively significant. FUEL and IP have a significantly positive link with the ASI in all quantiles. The coefficient of EX is negative and significant only in the lower quantiles, unlike in Model 1. The results of the OLS analysis show that the coefficients of OBTE and IP are positive and significant. The d9/11 dummy variable has a negative and significant influence, but dSARS and EX have no significant effect on the ASI. Moreover, the pseudo R-squared values show that the lower quantiles have greater explanatory power than the higher quantiles, similar to the result of Model 1.

In Model 3, the full sample is used with EPU, d9/11, and dSARS (see Table 2). (The OLS and QR results of Models 1 and 2 are omitted for convenience.) We find a combined effect on the ASI using EPU and the dummy variables. The EPU and dummy variables negatively influence the ASI. This study thus suggests that the ASI has a negative link with EPU, d9/11, dSARS, and EX, but a positive relationship with OBTE, FUEL, and IP. The reported significance levels of the coefficients and pseudo R-squared values are similar to those in Model 2 in the OLS analysis.

Table 2. Model 3 results for OLS and QR: Influence on the ASI

\begin{tabular}{|c|c|c|c|c|c|c|c|c|c|c|}
\hline \multirow{3}{*}{ Variables } & \multirow{3}{*}{ OLS } & \multicolumn{9}{|c|}{ QR } \\
\hline & & \multicolumn{3}{|c|}{$\begin{array}{l}\text { Bearish market } \\
\text { (Lower quantiles) }\end{array}$} & \multicolumn{3}{|c|}{$\begin{array}{c}\text { Normal market } \\
\text { (Medium quantiles) }\end{array}$} & \multicolumn{3}{|c|}{$\begin{array}{c}\text { Bullish market } \\
\text { (Upper quantiles) }\end{array}$} \\
\hline & & $\mathrm{Q}_{0.1}$ & $\mathrm{Q}_{0.2}$ & $\mathrm{Q}_{0.3}$ & $\mathrm{Q}_{0.4}$ & $\mathrm{Q}_{0.5}$ & $\mathrm{Q}_{0.6}$ & $\mathrm{Q}_{0.7}$ & $\mathrm{Q}_{0.8}$ & $\mathrm{Q}_{0.9}$ \\
\hline \multirow{2}{*}{$\ln (\mathrm{EPU})$} & 0.010 & 0.056 & 0.090 & 0.062 & 0.008 & -0.057 & $-0.157^{\mathrm{a}}$ & $-0.185^{\mathrm{a}}$ & $-0.229^{a}$ & $-0.169^{a}$ \\
\hline & $(0.059)$ & $(0.039)$ & $(0.089)$ & $(0.057)$ & $(0.078)$ & $(0.087)$ & $(0.057)$ & $(0.048)$ & $(0.040)$ & $(0.055)$ \\
\hline \multirow{2}{*}{$\ln$ (OBTE) } & \begin{tabular}{|l|}
$0.361^{\mathrm{c}}$ \\
\end{tabular} & -0.429 & 0.279 & 0.548 & $0.608^{\mathrm{a}}$ & $0.445^{\mathrm{a}}$ & $0.525^{\mathrm{b}}$ & 0.365 & 0.166 & 0.264 \\
\hline & $(0.209)$ & $(0.193)$ & $(0.258)$ & $(0.385)$ & $(0.219)$ & $(0.160)$ & $(0.216)$ & $(0.225)$ & $(0.248)$ & $(0.287)$ \\
\hline \multirow{2}{*}{$\ln (\mathrm{FUEL})$} & $0.509^{\mathrm{a}}$ & $0.143^{c}$ & $0.303^{\mathrm{a}}$ & $0.359^{\mathrm{a}}$ & $0.502^{\mathrm{a}}$ & $0.511^{\mathrm{a}}$ & $0.539^{\mathrm{a}}$ & $0.588^{\mathrm{a}}$ & $0.675^{\mathrm{a}}$ & $0.860^{\mathrm{a}}$ \\
\hline & $(0.063)$ & $(0.075)$ & $(0.082)$ & $(0.078)$ & $(0.113)$ & $(0.044)$ & $(0.054)$ & $(0.080)$ & $(0.109)$ & $(0.080)$ \\
\hline \multirow{2}{*}{$\ln (\mathrm{EX})$} & -0.417 & $-2.167^{\mathrm{a}}$ & $-1.521^{\mathrm{a}}$ & $-1.143^{\mathrm{b}}$ & -0.575 & -0.437 & -0.010 & 0.365 & 0.017 & 0.294 \\
\hline & (0.296) & $(0.263)$ & $(0.445)$ & $(0.481)$ & $(0.722)$ & $(0.622)$ & $(0.464)$ & $(0.225)$ & $(0.128)$ & $(0.494)$ \\
\hline \multirow{2}{*}{$\ln (\mathrm{IP})$} & $1.231^{\mathrm{a}}$ & $1.539^{\mathrm{a}}$ & $1.562^{\mathrm{a}}$ & $1.431^{\mathrm{a}}$ & $1.325^{\mathrm{a}}$ & $1.235^{\mathrm{a}}$ & $1.329^{\mathrm{a}}$ & $1.124^{\mathrm{a}}$ & $1.036^{\mathrm{a}}$ & $0.742^{\mathrm{a}}$ \\
\hline & $(0.156)$ & $(0.058)$ & $(0.053)$ & $(0.115)$ & $(0.187)$ & $(0.184)$ & $(0.334)$ & $(0.282)$ & $(0.322)$ & $(0.271)$ \\
\hline \multirow{2}{*}{ d9/11 } & $-0.673^{\mathrm{a}}$ & $-0.413^{\mathrm{a}}$ & $-0.446^{\mathrm{a}}$ & $-0.550^{\mathrm{a}}$ & $-0.588^{a}$ & $-0.506^{\mathrm{a}}$ & $-0.600^{\mathrm{a}}$ & $-0.688^{\mathrm{a}}$ & $-0.308^{a}$ & $-0.317^{\mathrm{a}}$ \\
\hline & $(0.178)$ & $(0.097)$ & $(0.092)$ & $(0.119)$ & $(0.155)$ & $(0.117)$ & $(0.113)$ & $(0.209)$ & $(0.205)$ & $(0.186)$ \\
\hline \multirow{2}{*}{ dSARS } & -0.249 & 0.088 & -0.079 & $-0.206^{\mathrm{b}}$ & $-0.243^{\mathrm{a}}$ & $-0.145^{a}$ & $-0.216^{\mathrm{a}}$ & $-0.280^{\mathrm{a}}$ & $-0.247^{\mathrm{a}}$ & $-0.347^{a}$ \\
\hline & $(0.186)$ & $(0.114)$ & $(0.115)$ & $(0.087)$ & $(0.007)$ & $(0.013)$ & $(0.074)$ & $(0.053)$ & $(0.040)$ & $(0.036)$ \\
\hline \multirow{2}{*}{ Constant } & 3.010 & $13.636^{\mathrm{a}}$ & $8.759^{\mathrm{a}}$ & $6.858^{\mathrm{b}}$ & 3.605 & 3.420 & 0.563 & 0.544 & 2.168 & 1.264 \\
\hline & $(2.112)$ & $(2.079)$ & $(3.252)$ & $(3.329)$ & (5.299) & $(4.440)$ & $(4.038)$ & $(2.772)$ & $(1.464)$ & $(3.456)$ \\
\hline $\begin{array}{l}\mathrm{R}^{2} \text { or } \\
\text { Pseudo } \\
\mathrm{R}^{2}\end{array}$ & 0.731 & 0.620 & 0.581 & 0.540 & 0.494 & 0.456 & 0.429 & 0.413 & 0.387 & 0.399 \\
\hline
\end{tabular}

Note: Standard errors are in parentheses. $a=p<1 \% ; b=p<5 \% ; c=p<10 \%$. 
These results support Hypothesis 1, meaning that an increase in EPU decreases the ASI in Korea and that the link between EPU and the ASI is stronger in bullish markets in Korea than in other markets. They also support Hypothesis 2 that an increase in global travel crises, such as 9/11 and the SARS outbreak, which increases EPU, decreases the ASI in Korea. In particular, 9/11 has a significant link with the ASI in all quantiles. Meanwhile, the impact of SARS on the ASI is stronger in a bullish market in Korea than in other markets.

Figures 4, 5, and 6 depict the results of the OLS and QR approaches in all quantiles for Models 1, 2, and 3, respectively. In addition, they show the trends between the size quantile and coefficients of the explanatory variables. Figures 4, 5, and 6 demonstrate that FUEL and IP have positive coefficients throughout the quantile distribution. Monotonic decreases in responsiveness are shown for EPU, dSARS, and IP, while FUEL and EX exhibit upward trends.

Tables 3, 4 and 5 show the results of the slope equality test for the asymmetric model suggested by Koenker and Bassett (1982). We use the Wald test with the following null hypotheses $\left(\mathrm{H}_{\mathrm{o}}\right): \beta_{0.1}=\beta_{0.9}, \beta_{0.2}=\beta_{0.8}, \beta_{0.3}=\beta_{0.7}, \beta_{0.4}=\beta_{0.6}, \beta_{0.1}=\beta_{0.5}$, and $\beta_{0.5}=\beta_{0.9}$. As shown in the tables, the null hypothesis of quantile slope equality for the explanatory variables is rejected in most of the quantiles, including the lower and higher quantiles. Moreover, the null hypotheses of the equality of the slope coefficients in all quantiles are rejected at the 5\% significance level for EPU, d9/11, and dSARS. Overall, these results suggest that the estimated coefficients are not constant across quantiles.
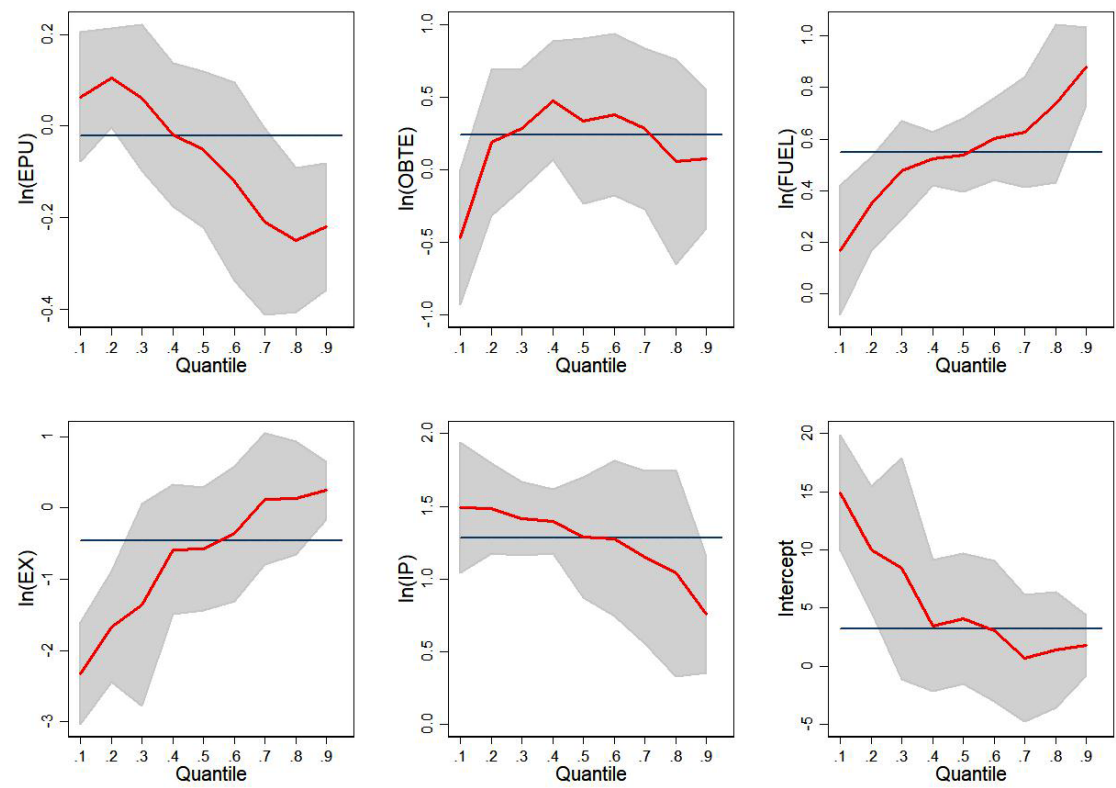

Note: The horizontal lines represent the OLS-estimated impacts of the explanatory variables on the $\tau$ th quantile of the ASI, while the curves are the QR-estimated impacts. That is, each graph shows the estimated QR coefficients along with the $95 \%$ confidence intervals for the explanatory variables on the vertical $\mathrm{y}$-axis across the quantile spectrum of the ASI distribution for $0 \leq \tau \leq 1$ on the horizontal $\mathrm{x}$-axis.

Figure 4. Model 1: Plot of the QR coefficient of the ASI 

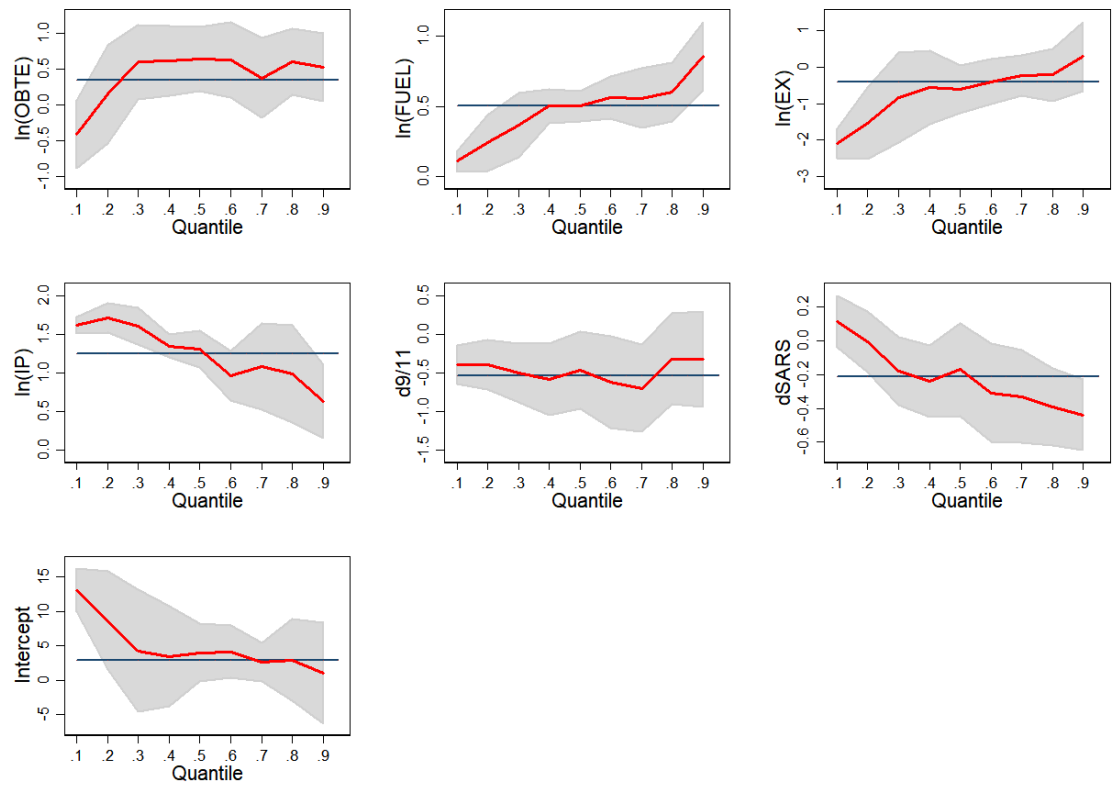

Note: See note to Figure 4.

Figure 5. Model 2: Plot of the QR coefficient of the ASI
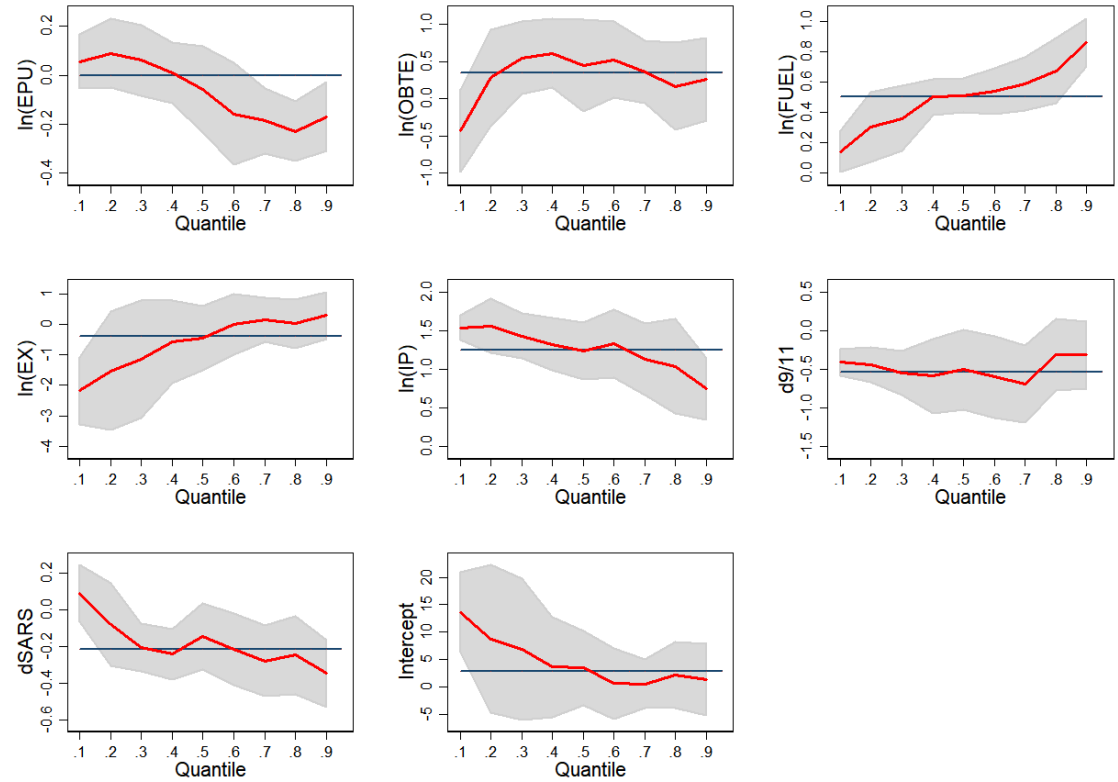

Note: See note to Figure 4.

Figure 6. Model 3: Plot of the QR coefficient of the ASI 
Table 3. Model 1: Results of the symmetric quantile test

\begin{tabular}{|c|c|c|c|c|c|c|}
\hline $\mathrm{H}_{\mathrm{o}}$ & $\beta_{0.1}=\beta_{0.9}$ & $\beta_{0.2}=\beta_{0.8}$ & $\beta_{0.3}=\beta_{0.7}$ & $\beta_{0.4}=\beta_{0.6}$ & $\beta_{0.1}=\beta_{0.5}$ & $\beta_{0.5}=\beta_{0.9}$ \\
\hline \multirow{2}{*}{$\ln (\mathrm{EPU})$} & $18.14^{\mathrm{a}}$ & $19.46^{\mathrm{a}}$ & $4.96^{\mathrm{b}}$ & $9.68^{\mathrm{a}}$ & $7.00^{\mathrm{a}}$ & $13.02^{\mathrm{a}}$ \\
\cline { 2 - 7 } & $(0.000)$ & $(0.000)$ & $(0.027)$ & $(0.002)$ & $(0.009)$ & $(0.000)$ \\
\hline \multirow{3}{*}{$\ln (\mathrm{OBTE})$} & $9.48^{\mathrm{a}}$ & $63.56^{\mathrm{a}}$ & 0.01 & $12.04^{\mathrm{a}}$ & $12.57^{\mathrm{a}}$ & $11.34^{\mathrm{a}}$ \\
\cline { 2 - 7 } & $(0.002)$ & $(0.000)$ & $(0.927)$ & $(0.000)$ & $(0.000)$ & $(0.000)$ \\
\hline \multirow{2}{*}{$\ln (\mathrm{FUEL})$} & $19.22^{\mathrm{a}}$ & $8.82^{\mathrm{a}}$ & $7.38^{\mathrm{a}}$ & $5.04^{\mathrm{b}}$ & $37.92^{\mathrm{a}}$ & $13.47^{\mathrm{a}}$ \\
\cline { 2 - 7 } & $(0.000)$ & $(0.003)$ & $(0.007)$ & $(0.025)$ & $(0.000)$ & $(0.000)$ \\
\hline \multirow{2}{*}{$\ln (\mathrm{EX})$} & $19.35^{\mathrm{a}}$ & $12.00^{\mathrm{a}}$ & $23.77^{\mathrm{a}}$ & $7.21^{\mathrm{a}}$ & $10.02^{\mathrm{a}}$ & $7.01^{\mathrm{a}}$ \\
\cline { 2 - 7 } & $(0.000)$ & $(0.000)$ & $(0.000)$ & $(0.008)$ & $(0.002)$ & $(0.009)$ \\
\hline \multirow{2}{*}{$\ln (\mathrm{IP})$} & $18.23^{\mathrm{a}}$ & $8.72^{\mathrm{a}}$ & $4.97^{\mathrm{b}}$ & $7.09^{\mathrm{a}}$ & $14.49^{\mathrm{a}}$ & $13.56^{\mathrm{a}}$ \\
\cline { 2 - 7 } & $(0.000)$ & $(0.003)$ & $(0.027)$ & $(0.008)$ & $(0.000)$ & $(0.000)$ \\
\hline
\end{tabular}

Note: The F-statistics are shown with p-values in parentheses. $a=p<1 \% ; b=p<5 \% ; c=p<10 \%$.

Table 4. Model 2: Results of the symmetric quantile test

\begin{tabular}{|c|c|c|c|c|c|c|}
\hline $\mathrm{H}_{\mathrm{o}}$ & $\beta_{0.1}=\beta_{0.9}$ & $\beta_{0.2}=\beta_{0.8}$ & $\beta_{0.3}=\beta_{0.7}$ & $\beta_{0.4}=\beta_{0.6}$ & $\beta_{0.1}=\beta_{0.5}$ & $\beta_{0.5}=\beta_{0.9}$ \\
\hline \multirow{2}{*}{$\ln ($ OBTE $)$} & $22.93^{\mathrm{a}}$ & $4.52^{\mathrm{b}}$ & $5.66^{\mathrm{b}}$ & $67.65^{\mathrm{a}}$ & $18.08^{\mathrm{a}}$ & $5.25^{\mathrm{b}}$ \\
\cline { 2 - 7 } & $(0.000)$ & $(0.035)$ & $(0.018)$ & $(0.000)$ & $(0.000)$ & $(0.023)$ \\
\hline \multirow{2}{*}{$\ln$ (FUEL) } & $10.63^{\mathrm{a}}$ & $6.08^{\mathrm{b}}$ & $10.42^{\mathrm{a}}$ & $5.39^{\mathrm{b}}$ & $28.54^{\mathrm{a}}$ & $5.03^{\mathrm{b}}$ \\
\cline { 2 - 7 } & $(0.001)$ & $(0.014)$ & $(0.001)$ & $(0.021)$ & $(0.000)$ & $(0.025)$ \\
\hline \multirow{2}{*}{$\ln (\mathrm{EX})$} & $57.12^{\mathrm{a}}$ & $15.09^{\mathrm{a}}$ & $13.35^{\mathrm{a}}$ & $5.82^{\mathrm{b}}$ & $19.82^{\mathrm{a}}$ & $11.44^{\mathrm{a}}$ \\
\cline { 2 - 7 } & $(0.000)$ & $(0.000)$ & $(0.000)$ & $(0.017)$ & $(0.000)$ & $(0.000)$ \\
\hline \multirow{2}{*}{$\ln (\mathrm{IP})$} & $34.45^{\mathrm{a}}$ & $8.17^{\mathrm{a}}$ & $5.34^{\mathrm{b}}$ & $9.34^{\mathrm{a}}$ & $5.00^{\mathrm{b}}$ & $12.17^{\mathrm{a}}$ \\
\cline { 2 - 7 } & $(0.000)$ & $(0.005)$ & $(0.022)$ & $(0.002)$ & $(0.026)$ & $(0.000)$ \\
\hline \multirow{2}{*}{$\mathrm{d} 9 / 11$} & $12.17^{\mathrm{a}}$ & $10.58^{\mathrm{a}}$ & $8.89^{\mathrm{a}}$ & $7.72^{\mathrm{a}}$ & $9.41^{\mathrm{a}}$ & $4.41^{\mathrm{b}}$ \\
\cline { 2 - 7 } & $(0.000)$ & $(0.001)$ & $(0.003)$ & $(0.000)$ & $(0.002)$ & $(0.037)$ \\
\hline \multirow{2}{*}{$\mathrm{d}$ dSARS } & $25.08^{\mathrm{a}}$ & $5.02^{\mathrm{b}}$ & $27.14^{\mathrm{a}}$ & $38.03^{\mathrm{a}}$ & $68.85^{\mathrm{a}}$ & $4.21^{\mathrm{b}}$ \\
\cline { 2 - 7 } & $(0.000)$ & $(0.026)$ & $(0.000)$ & $(0.000)$ & $(0.000)$ & $(0.041)$ \\
\hline
\end{tabular}

Note: See note to Table 3.

Table 5. Model 3: Results of the symmetric quantile test

\begin{tabular}{|c|c|c|c|c|c|c|}
\hline $\mathrm{H}_{\mathrm{o}}$ & $\beta_{0.1}=\beta_{0.9}$ & $\beta_{0.2}=\beta_{0.8}$ & $\beta_{0.3}=\beta_{0.7}$ & $\beta_{0.4}=\beta_{0.6}$ & $\beta_{0.1}=\beta_{0.5}$ & $\beta_{0.5}=\beta_{0.9}$ \\
\hline \multirow{2}{*}{$\ln (\mathrm{EPU})$} & $10.14^{\mathrm{a}}$ & $8.85^{\mathrm{a}}$ & $7.53^{\mathrm{a}}$ & $24.32^{\mathrm{a}}$ & $3.95^{\mathrm{b}}$ & $6.50^{\mathrm{b}}$ \\
\cline { 2 - 7 } & $(0.002)$ & $(0.003)$ & $(0.007)$ & $(0.000)$ & $(0.048)$ & $(0.012)$ \\
\hline \multirow{2}{*}{$\ln ($ OBTE $)$} & $20.00^{\mathrm{a}}$ & $7.77^{\mathrm{a}}$ & $5.09^{\mathrm{b}}$ & $9.11^{\mathrm{a}}$ & $6.85^{\mathrm{a}}$ & $4.37^{\mathrm{b}}$ \\
\cline { 2 - 7 } & $(0.000)$ & $(0.005)$ & $(0.025)$ & $(0.000)$ & $(0.009)$ & $(0.038)$ \\
\hline \multirow{2}{*}{$\ln$ (FUEL) } & $45.20^{\mathrm{a}}$ & $12.47^{\mathrm{a}}$ & $10.29^{\mathrm{a}}$ & $28.96^{\mathrm{a}}$ & $33.16^{\mathrm{a}}$ & $60.43^{\mathrm{a}}$ \\
\cline { 2 - 7 } & $(0.000)$ & $(0.000)$ & $(0.001)$ & $(0.000)$ & $(0.000)$ & $(0.000)$ \\
\hline
\end{tabular}


End of Table 5

\begin{tabular}{|c|c|c|c|c|c|c|}
\hline $\mathrm{H}_{\mathrm{o}}$ & $\beta_{0.1}=\beta_{0.9}$ & $\beta_{0.2}=\beta_{0.8}$ & $\beta_{0.3}=\beta_{0.7}$ & $\beta_{0.4}=\beta_{0.6}$ & $\beta_{0.1}=\beta_{0.5}$ & $\beta_{0.5}=\beta_{0.9}$ \\
\hline \multirow{3}{*}{$\ln (\mathrm{EX})$} & $10.76^{\mathrm{a}}$ & $16.89^{\mathrm{a}}$ & $14.68^{\mathrm{a}}$ & $6.89^{\mathrm{a}}$ & $5.44^{\mathrm{b}}$ & $4.26^{\mathrm{b}}$ \\
\cline { 2 - 7 } & $(0.001)$ & $(0.000)$ & $(0.000)$ & $(0.009)$ & $(0.021)$ & $(0.040)$ \\
\hline \multirow{2}{*}{$\ln (\mathrm{IP})$} & $15.72^{\mathrm{a}}$ & $6.42^{\mathrm{b}}$ & $6.91^{\mathrm{a}}$ & $3.74^{\mathrm{c}}$ & $12.95^{\mathrm{a}}$ & $7.09^{\mathrm{a}}$ \\
\cline { 2 - 7 } & $(0.000)$ & $(0.012)$ & $(0.009)$ & $(0.054)$ & $(0.000)$ & $(0.008)$ \\
\hline \multirow{2}{*}{$\mathrm{d} 9 / 11$} & $9.62^{\mathrm{a}}$ & $7.10^{\mathrm{a}}$ & $6.43^{\mathrm{b}}$ & $5.05^{\mathrm{b}}$ & $9.52^{\mathrm{a}}$ & $30.08^{\mathrm{a}}$ \\
\cline { 2 - 7 } & $(0.000)$ & $(0.008)$ & $(0.012)$ & $(0.025)$ & $(0.002)$ & $(0.000)$ \\
\hline \multirow{2}{*}{$\mathrm{d}$ SARS } & $8.21^{\mathrm{a}}$ & $12.77^{\mathrm{a}}$ & $7.30^{\mathrm{a}}$ & $37.02^{\mathrm{a}}$ & $12.77^{\mathrm{a}}$ & $14.68^{\mathrm{a}}$ \\
\cline { 2 - 7 } & $(0.003)$ & $(0.000)$ & $(0.007)$ & $(0.000)$ & $(0.000)$ & $(0.000)$ \\
\hline
\end{tabular}

Note: See note to Table 3.

\section{Discussion}

Given that Korea's ASI is adversely affected by risks (see Figure 2), the present study investigates the impact of the ASI using travel crises, such as 9/11 and SARS, as dummy variables. This research analyzes the factors affecting Korean airlines, as the growth of tourism companies in Korea is closely related to the country's economic growth. The presented empirical analysis reveals the impact of EPU on Korea's ASI. EPU has long been known to have a strong impact on stock price volatility and financial markets (Baker et al., 2016; Demir \& Ersan, 2018).

In the empirical analysis, $\mathrm{QR}$ is used to estimate the link between the stock price index, which shows the growth of airlines, and Korea's EPU. We further explore the impact of EPU by dividing the Korean stock market into bearish, normal, and bullish markets. In addition, since airlines are sensitive to crisis situations and risks affecting tourists, these factors may play an important role in explaining stock prices. As OLS regression can only estimate the conditional mean of a dependent variable, this research employs the QR approach to address this issue as well as adds the asymptotic joint distribution of the OLS and QR approaches. In addition, it is motivated by tourism studies that state that stock market investors expect a bullish market if the invested companies are deemed to be profitable in the near future. As investors forecast rapid economic growth when stock prices rise, a significant increase in stock prices improves market capitalization, meaning that the invested companies may experience higher sales and firm value (Chen, 2016; Yun \& Yoon, 2019).

The findings of this study are consistent with those of previous studies that show that higher EPU lowers stock prices (Antonakakis et al., 2013; Demir \& Ersan, 2018; Jin et al., 2019). The empirical results support both the hypothesized linkages. They can be summarized as follows. First, the ASI has a negative link with EPU and the dummy variables, which lowers outbound tourist consumption. In addition, the coefficient of tourism expenditure is positive in most quantiles. The coefficients of EX also support the portfolio balance approach. When foreign capital flows out of (into) stock markets, there is the depreciation (appreciation) of currencies. This indicates the negative link between the ASI and EX. FUEL and IP 
have a significantly positive association with the ASI in all quantiles. The effects of both 9/11 and SARS on the ASI are similar. These dummy variables have significantly negative coefficients. In particular, 9/11 has a significantly negative influence on the ASI in all quantiles in the three models. The results suggest that terrorism and disease outbreaks have an influence, as travelers' safety is likely to be a prerequisite for international travel. This study shows that the dummy variables have a significantly negative association with the ASI. Hence, the empirical analysis confirms that $9 / 11$ and the SARS outbreak have a significant impact on the stock prices of airlines in Korea.

\section{Conclusions}

This study extends the literature by investigating the effect of tourism uncertainty, including EPU and travel crises, such as 9/11 and SARS, on the ASI in Korea. For the empirical study, we use data on the EPU index and travel crises, which influence outbound tourism and investors in airline stock markets in Korea, from 2001 to 2018. This research extends the scope of the analysis to the Korean stock market. The contribution of this study is thus twofold. First, it is shown that EPU has a strong influence on the ASI, suggesting that the stock market authorities should carefully observe changes in the trends of these variables. Second, travel crises have a negative effect on the ASI. This study thus contributes to research by demonstrating that the importance of safety is directly related to an airline's earnings and stock prices. Hence, the chief executive officers of airlines should make quick decisions and provide solutions to overcome EPU.

The limitations of this research are as follows. First, we explore the link between tourism uncertainty and the ASI only in the Korean market. Further studies should consider more countries, such as the BRIC nations. Second, this study uses the QR approach to estimate the models, but several methodologies could be used in future studies. In particular, there are other methods of analyzing the link between EPU and the stock market. For example, co-movements based on the dynamic conditional correlation model could be used in future research, which could also offer more policy impacts. Alternative economic shocks and airline stock price measures could also be employed.

\section{References}

Ajayi, R. A., \& Mougoue, M. (1996). On the dynamic relation between stock prices and exchange rates. Journal of Financial Research, 19(2), 193-207. https://doi.org/10.1111/j.1475-6803.1996.tb00593.x

Alegre, J., Mateo, S., \& Pou, L. (2013). Tourism participation and expenditure by Spanish households: The effects of the economic crisis and unemployment. Tourism Management, 39, 37-49. https://doi.org/10.1016/j.tourman.2013.04.002

Altunbaş, Y., \& Thornton, J. (2019). The impact of financial development on income inequality: A quantile regression approach. Economics Letters, 175, 51-56.

https://doi.org/10.1016/j.econlet.2018.12.030

Antonakakis, N., Chatziantoniou, I., \& Filis, G. (2013). Dynamic co-movements of stock market returns, implied volatility and policy uncertainty. Economics Letters, 120(1), 87-92.

https://doi.org/10.1016/j.econlet.2013.04.004 
Arana, J. E., \& León, C. J. (2008). The impact of terrorism on tourism demand. Annals of Tourism Research, 35(2), 299-315. https://doi.org/10.1016/j.annals.2007.08.003

Asprem, M. (1989). Stock prices, asset portfolios and macroeconomic variables in ten European countries. Journal of Banking and Finance, 13(4-5), 589-612.

https://doi.org/10.1016/0378-4266(89)90032-0

Baker, S. R., Bloom, N., \& Davis, S. J. (2016). Measuring economic policy uncertainty. Quarterly Journal of Economics, 131(4), 1593-1636. https://doi.org/10.1093/qje/qjw024

Balli, F., Shahzad, S. J. H., \& Uddin, G. S. (2018). A tale of two shocks: What do we learn from the impacts of economic policy uncertainties on tourism? Tourism Management, 68, 470-475. https://doi.org/10.1016/j.tourman.2018.04.008

Bang, H., \& Park, M. (2018). Global value chain and its impact on the linkage between exchange rate and export: Cases of China, Japan and Korea. World Economy, 41(9), 2552-2576. https://doi.org/10.1111/twec.12595

Bonham, C., Edmonds, C., \& Mak, J. (2006). The impact of 9/11 and other terrible global events on tourism in the United States and Hawaii. Journal of Travel Research, 45(1), 99-110. https://doi.org/10.1177/0047287506288812

Broadstock, D. C., Cao, H., \& Zhang, D. (2012). Oil shocks and their impact on energy related stocks in China. Energy Economics, 34(6), 1988-1895. https://doi.org/10.1016/j.eneco.2012.08.008

Chang, B. H. (2020). Oil prices and E7 stock prices: An asymmetric evidence using multiple threshold nonlinear ARDL model. Environmental Science and Pollution Research, 27, 44183-44194. https://doi.org/10.1007/s11356-020-10277-2

Chang, T., Chen, W.-Y., Gupta, R., \& Nguyen, D. K. (2015). Are stock prices related to the political uncertainty index in OECD countries? Evidence from the bootstrap panel causality test. Economic Systems, 39(2), 288-300. https://doi.org/10.1016/j.ecosys.2014.10.005

Chang, W. S., \& Lee, Y.-H. (2017). The Macroeconomic contribution to foreign-exchange earnings from tourism in Taiwan. Current Issues in Tourism, 20(11), 1110-1115.

https://doi.org/10.1080/13683500.2016.1206062

Chen, M.-H. (2007). Macro and non-macro explanatory factors of Chinese hotel stock returns. International Journal of Hospitality Management, 26(4), 991-1004. https://doi.org/10.1016/j.ijhm.2006.04.002

Chen, M.-H. (2016). A quantile regression analysis of tourism market growth effect on the hotel industry. International Journal of Hospitality Management, 52, 117-120. https://doi.org/10.1016/j.ijhm.2015.10.001

Chen, M.-H., \& Kim, H. J. (2010). Tourism expansion and corporate earnings in the tourism industry. Service Industries Journal, 30(6), 947-964. https://doi.org/10.1080/02642060802342646

Chen, M.-H., Kim, W. G., \& Kim, H. J. (2005). The impact of macroeconomic and non-macroeconomic forces on hotel stock returns. International Journal of Hospitality Management, 24(2), 243-258. https://doi.org/10.1016/j.ijhm.2004.06.008

Chen, M.-P., Lee, C.-C., Lin, Y.-H., \& Chen, W.-Y. (2018). Did the SARS epidemic weaken the integration of Asian stock markets? Evidence from smooth time-varying cointegration analysis. Economic Research-Ekonomska Istraživanja, 31(1), 908-923. https://doi.org/10.1080/1331677X.2018.1456354

Christou, C., Cunado, J., Gupta, R., \& Hassapis, C. (2017). Economic policy uncertainty and stock market returns in PacificRim countries: Evidence based on a Bayesian panel VAR model. Journal of Multinational Financial Management, 40, 92-102. https://doi.org/10.1016/j.mulfin.2017.03.001

Demir, E., \& Ersan, O. (2018). The impact of economic policy uncertainty on stock returns of Turkish tourism companies. Current Issues in Tourism, 21(8), 847-855.

https://doi.org/10.1080/13683500.2016.1217195 
Demir, E., \& Gozgor, G. (2018). Does economic policy uncertainty affect Tourism? Annals of Tourism Research, 69, 15-17. https://doi.org/10.1016/j.annals.2017.12.005

Demir, E., Alici, Z. A., \& Lau, M. C. K. (2017). Macro explanatory factors of Turkish tourism companies's stock returns. Asia Pacific Journal of Tourism Research, 22(4), 370-380. https://doi.org/10.1080/10941665.2016.1271814

Dhariwal, R. (2005). Tourist arrivals in India: How important are domestic disorders? Tourism Economics, 11(2), 185-205. https://doi.org/10.5367/0000000054183522

Dolnicar, S. (2005). Understanding barriers to leisure travel: Tourist fears as a marketing basis. Journal of Vacation Marketing, 11(3), 197-208. https://doi.org/10.1177/1356766705055706

Dragouni, M., Filis, G., Gavriilidis, K., \& Santamaria, D. (2016). Sentiment, mood and outbound tourism demand. Annals of Tourism Research, 60, 80-96. https://doi.org/10.1016/j.annals.2016.06.004

Dritsakis, N. (2004). Tourism as a long-run economic growth factor: An empirical investigation for Greece using a causality analysis. Tourism Economics, 10(3), 305-316. https://doi.org/10.5367/0000000041895094

Economic Policy Uncertainty Index for South Korea. (2018). South Korea Monthly Index. http://www.policyuncertainty.com/korea_monthly.html

Gholipour, H. F., Tajaddini, R., \& Al-Mulali, U. (2014). Does personal freedom influence outbound tourism? Tourism Management, 41, 19-25. https://doi.org/10.1016/j.tourman.2013.08.010

Gozgor, G., \& Ongan, S. (2017). Economic policy uncertainty and tourism demand: Empirical evidence from the USA. International Journal of Tourism Research, 19(1), 99-106. https://doi.org/10.1002/jtr.2089

Hannam, K., Butler, G., \& Paris, C. M. (2014). Developments and key issues in tourism mobilities. Annals of Tourism Research, 44, 171-185. https://doi.org/10.1016/j.annals.2013.09.010

International Monetary Fund. (2019). World economic and financial surveys. World Economic Outlook (WEO) Database. https://www.imf.org/external/pubs/ft/weo/2019/01/weodata/index.aspx

Jang, S. C., \& Chen, M. H. (2008). Financial portfolio approach to optimal tourist market mixes. Tourism Management, 29(4), 761-770. https://doi.org/10.1016/j.tourman.2007.09.003

Jin, X., Chen, Z., \& Yang, X. (2019). Economic policy uncertainty and stock price crash risk. Accounting \& Finance, 58(5), 1291-1318. https://doi.org/10.1111/acfi.12455

Kang, W., Ratti, R. A., \& Yoon, K. H. (2015). The impact of oil price shocks on the stock market return and volatility relationship. Journal of International Financial Markets, Institutions \& Money, 34, 41-54. https://doi.org/10.1016/j.intfin.2014.11.002

Karimi, M. S., Khan, A. A., \& Karamelikli, H. (2019). Asymmetric effects of real exchange rate on inbound tourist arrivals in Malaysia: An analysis of price rigidity. International Journal of Tourism Research, 21(2), 156-164. https://doi.org/10.1002/jtr.2249

Kavussanos, M. G., Marcoulis, S. N., \& Arkoulis, A. G. (2002). Macroeconomic factors and international industry returns. Applied Financial Economics, 12(12), 923-931. https://doi.org/10.1080/09603100110069374

Kim, H.-B., Park, J.-H., Lee, S. K., \& Jang, S. (2012). Do expectations of future wealth increase outbound tourism? Evidence from Korea. Tourism Management, 33(5), 1141-1147. https://doi.org/10.1016/j.tourman.2011.11.017

Kim, J., \& Kim, S. (2017). Effects of monetary policy shocks on farm prices and exchange rates in Korea. Emerging Markets Finance \& Trade, 53(11), 2450-2462. https://doi.org/10.1080/1540496X.2017.1329143

Ko, J.-H., \& Lee, C.-M. (2015). International economic policy uncertainty and stock prices: Wavelet approach. Economics Letters, 134, 118-122. https://doi.org/10.1016/j.econlet.2015.07.012 
Koenker, R., \& Bassett, G. (1978). Regression quantiles. Econometrica, 46(1), 33-50. https://doi.org/10.2307/1913643

Koenker, R., \& Bassett, G. (1982). Robust tests for heteroscedasticity based on regression quantiles. Econometrica, 50(1), 43-61. https://doi.org/10.2307/1912528

Kolaric, S., \& Schiereck, D. (2016). Are stock markets efficient in the face of fear? Evidence from the terrorist attacks in Paris and Brussels. Finance Research Letters, 18, 306-310. https://doi.org/10.1016/j.frl.2016.05.003

Kristjanpoller, W. D., \& Concha, D. (2016). Impact of fuel price fluctuations on airline stock returns. Applied Energy, 178, 496-504. https://doi.org/10.1016/j.apenergy.2016.06.089

Lee, C.-C., \& Chang, C.-P. (2008). Tourism development and economic growth: A closer look at panels. Tourism Management, 29(1), 180-192. https://doi.org/10.1016/j.tourman.2007.02.013

Li, X.-M., \& Peng, L. (2017). US economic policy uncertainty and co-movements between Chinese and US stock markets. Economic Modelling, 61, 27-39. https://doi.org/10.1016/j.econmod.2016.11.019

Lim, S. H., \& Hong, Y. (2014). Fuel hedging and airline operating costs. Journal of Air Transport Management, 36, 33-40. https://doi.org/10.1016/j.jairtraman.2013.12.009

Madanoglu, M., \& Ozdemir, O. (2019). Economic policy uncertainty and hotel operating performance. Tourism Management, 71, 443-452. https://doi.org/10.1016/j.tourman.2018.10.012

Miller, J. I., \& Ratti, R. A. (2009). Crude oil and stock markets: Stability, instability, and bubbles. Energy Economics, 31(4), 559-568. https://doi.org/10.1016/j.eneco.2009.01.009

Mnasri, A., \& Nechi, S. (2016). Impact of terrorist attacks on stock market volatility in emerging markets. Emerging Markets Review, 28, 184-202. https://doi.org/10.1016/j.ememar.2016.08.002

Napierala, T., \& Szutowski, D. (2018). The impact of localized innovations on the stock returns of tourism companies. International Journal of Tourism Research, 21(1), 108-121. https://doi.org/10.1002/jtr.2245

Narayan, P. K., \& Sharma, S. S. (2011). New evidence on oil price and firm returns. Journal of Banking \& Finance, 35(12), 3253-3262. https://doi.org/10.1016/j.jbankfin.2011.05.010

Narayan, P. K., Devpura, N., \& Wang, H. (2020). Japanese currency and stock market - What happened during the COVID-19 pandemic? Economic Analysis and Policy, 68, 191-198. https://doi.org/10.1016/j.eap.2020.09.014

Nguyen, C. P., Schinckus, C., \& Su, T. D. (2020). Economic policy uncertainty and demand for international tourism: An empirical study. Tourism Economics, 26(8), 1415-1430. https://doi.org/10.1177/1354816619900584

Nusair, S. A., \& Al-Khasawneh, J. A. (2018). Oil price shocks and stock market returns of the GCC countries: Empirical evidence from quantile regression analysis. Economic Change and Restructuring, 51(4), 339-372. https://doi.org/10.1007/s10644-017-9207-4

Nusair, S. A., \& Olson, D. (2019). The effects of oil price shocks on Asian exchange rates: Evidence from quantile regression analysis. Energy Economics, 78, 44-63. https://doi.org/10.1016/j.eneco.2018.11.009

Olya, H. G., \& Mehran, J. (2017). Modelling tourism expenditure using complexity theory. Journal of Business Research, 75, 147-158. https://doi.org/10.1016/j.jbusres.2017.02.015

Ongan, S., \& Gozgor, G. (2017). Tourism demand analysis: The impact of the economic policy uncertainty on the arrival of Japanese tourists to the USA. International Journal of Tourism Research, 20(3), 208-316. https://doi.org/10.1002/jtr.2182

Park, J., \& Ratti, R. A. (2008). Oil price shocks and stock markets in the US and 13 European countries. Energy Economics, 30(5), 2587-2608. https://doi.org/10.1016/j.eneco.2008.04.003 
Peng, G., Huiming, Z., \& Wanhai, Y. (2018). Asymmetric dependence between economic policy uncertainty and stock market returns in G7 and BRIC: A quantile regression approach. Finance Research Letters, 25, 251-258. https://doi.org/10.1016/j.frl.2017.11.001

Pine, P., \& McKercher, B. (2004). The impact of SARS on Hong Kong's tourism industry. International Journal of Contemporary Hospitality Management, 16(2), 139-143. https://doi.org/10.1108/09596110410520034

Rosselló, J., Santana-Gallego, M., \& Awan, W. (2017). Infectious disease risk and international tourism demand. Health Policy and Planning, 32(4), 538-548. https://doi.org/10.1093/heapol/czw177

Sadorsky, P. (1999). Oil price shocks and stock market activity. Energy Economics, 21(5), 449-469. https://doi.org/10.1016/S0140-9883(99)00020-1

Sheldon, P., \& Dwyer, L. (2010). The Global financial crisis and tourism: Perspectives of the academy. Journal of Travel Research, 49(1), 3-4. https://doi.org/10.1177/0047287509353191

Sinclair, M. T. (1998). Tourism and economic development: A survey. Journal of Development Studies, 34(5), 1-51. https://doi.org/10.1080/00220389808422535

Tsai, I.-C. (2012). The relationship between stock price index and exchange rate in Asian markets: A quantile regression approach. Journal of International Financial Markets, Institutions and Money, 22(3), 609-621. https://doi.org/10.1016/j.intfin.2012.04.005

UNWTO. (2019). UNWTO world tourism barometer and statistical annex, January 2019. World Tourism Barometer, 17(1). https://www.e-unwto.org/doi/abs/10.18111/wtobarometereng.2019.17.1.1

UNWTO. (2020). International tourism expected to decline over $70 \%$ in 2020 , back to levels of 30 years ago. World Tourism Barometer, 18(7).

https://www.e-unwto.org/doi/epdf/10.18111/wtobarometereng.2020.18.1.7

Veraros, N., Kasimati, E., \& Dawson, P. (2004). The 2004 Olympic games announcement and its effect on the Athens and Milan stock exchanges. Applied Economics Letters, 11(12), 749-753. https://doi.org/10.1080/1350485042000254584

Wan, Y. K. P. (2013). A comparison of the governance of tourism planning in the two special administrative regions (SARs) of China - Hong Kong and Macao. Tourism Management, 36, 164-177. https://doi.org/10.1016/j.tourman.2012.12.005

Wong, H. T. (2017). Real exchange rate returns and real stock price returns. International Review of Economics and Finance, 49, 340-352. https://doi.org/10.1016/j.iref.2017.02.004

Wong, K. K. F., \& Song, H. (2006). Do macroeconomic variables contain any useful information for predicting changes in hospitality stock indices? Journal of Hospitality and Tourism Research, 30(1), 16-33. https://doi.org/10.1177/1096348005284267

You, W., Guo, Y., Zhu, H., \& Tang, Y. (2017). Oil price shocks, economic policy uncertainty and industry stock returns in China: Asymmetric effects with quantile regression. Energy Economics, 68, 1-18. https://doi.org/10.1016/j.eneco.2017.09.007

Yun, X., \& Yoon, S.-M. (2019). Impact of oil price change on airline's stock price and volatility: Evidence from China and South Korea. Energy Economics, 78, 668-679.

https://doi.org/10.1016/j.eneco.2018.09.015 